Vietnam Academy of Science and Technology
Vietnam Journal of Earth Sciences
(VAttp://www.vjs.ac.vn/index.php/jse

\title{
New discovery of late early ordovician graptolites and dis- cussion on stratigraphic sequence of paleozoic sediments in the Dinh Ca - Trang Xa Section, Vo Nhai Disctrict, Thai Nguyen Province, Northeast Vietnam
}

\author{
Nguyen Huu Hung*, Nguyen Trung Minh, Doan Dinh Hung, Nguyen Ba Hung \\ Vietnam National Museum of Nature, Vietnam Academy of Science and Technology
}

Received 19 July 2016. Accepted 9 February 2017

\begin{abstract}
Sandstone, quartzitic sandstone rhythmically interbedded with siltstone, calcareous siltstone and cherty shale are largely exposed in the Dinh Ca - Trang Xa area, Vo Nhai District, Thai Nguyen Province, NE Vietnam. In previous studies, they were described as Mo Dong or Than Sa Formations (Middle-Upper Cambrian). The graptolite faunas newly discovered from the Dinh Ca Market - Na Mo - Dong Bo cross section are composed of Expansograptus urbanus (Monsen), Expansograptus abnormis (Hsu), Tetragraptus quadribrachiatus (Hall), T. approximatus Nicholson, T. pacificus Ruedemann, T. decipiens T.S. Hall, Schizograptus sp., belonging to the quadribrachiatus Biozone, indicating Floian Stage or late Early Ordovician. This serves as the basis for age determination and for establishing new lithostratigraphic units termed as the Dinh Ca Formation $\left(\mathrm{O}_{1} d c\right)$ and the Ba Nhat Member. The stratigraphic sequence of Paleozoic sediments in the Dinh Ca - Trang Xa area is also discussed in this paper.
\end{abstract}

Keywords: Graptolite faunas, late Early Ordovician, Dinh Ca Formation, Ba Nhat Member, Thai Nguyen, Vietnam.

(C)2017 Vietnam Academy of Science and Technology

\section{Introduction}

The location of graptolite Ordovic fauna collection and study of stratigraphic sequence including Ordovician, Devonian, and Carboniferous-Permian is shown in Figure 1. The area consists of low hilly and mountainous areas, ranging in elevation from $50-500 \mathrm{~m}$, and comprising mainly terrigenous, carbonate and cherty shale rocks. They are largely exposed

"Corresponding author, Email: hungcsdt@yahoo.com around the Dinh Ca Town, and in the Tien Phong, Phu Thuong, Ba Nhat, Tan Thanh, Na Mo, Dong Bo, Mo Dinh, Dong En, Lang Den, Trang Xa villages of Vo Nhai District, Thai Nguyen Province, about $30 \mathrm{~km}$ northeast of Thai Nguyen City, and $100 \mathrm{~km}$ from Ha Noi. Geographically, the study area is in the northeastern region of Viet Nam, belongs to the Song Hien Structure-facial Zone (Dovjikov et al., 1965), the Bac Son Miogeosynclinal Fold Zone (Le Duy Bach, 1985); or the Early Paleozoic Intracontinental Orogenic Belt of 
Northeast Viet Nam (Tran Van Tri, Vu Khuc (Eds.) 2011).

In this study, the new findings of Ordovician graptolite faunas are used to propose a new stratigraphic nomenclature for the Ordovician succession. The stratigraphic sequence of Paleozoic sediments in the Dinh Ca-Trang $\mathrm{Xa}$ area are also discussed here.

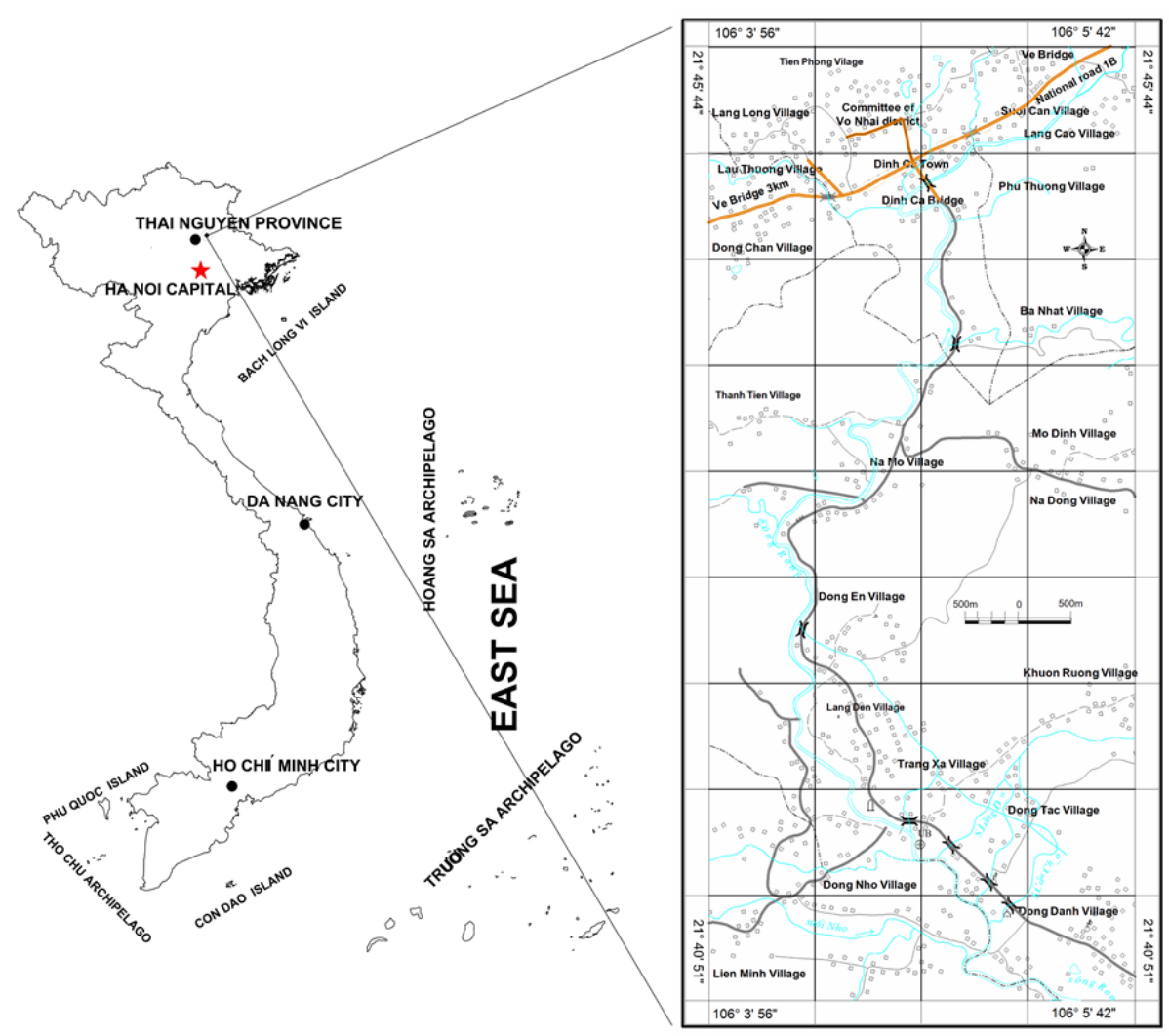

Figure 1. Sketch map showing outcrops of Paleozoic sedimens in the Dinh Ca - Trang Xa area

\section{Geological setting}

The Dinh Ca - Trang Xa area is chiefly Paleozoic sediments, which were mapped by Doan Ky Thuy et al. (1976, 2000) at 1:200.000 scale of the Lang Son Geological Sheet (Figure 2), and divided into the following lithostratigraphic units (Doan Ky Thuy (Ed.) 1976, 2000):

The Mo Dong Formation $\left(\varepsilon_{2} m d\right)$ composed of quartzite, quartzitic sandstone, siltstone, clay shale, $300 \mathrm{~m}$ thick, is considered as the lowermost formation of Cambrian sediments in the Dinh Ca - Trang Xa area.
The Than Sa Formation $\left(\varepsilon_{3} t s\right)$ is composed of two sub-formations, with the Lower Subformation $\left(\varepsilon_{3} t s 1\right)$ comprising clay shale, thin beds of polymictic sandstone, $500 \mathrm{~m}$ thick, and the Upper Subformation $\left(\varepsilon_{3} t s 2\right)$ containing polymictic sandstone, grey clayish shale, $350 \mathrm{~m}$ thick. The formation lies conformably on the Mo Dong Formation $\left(\varepsilon_{2} m d\right)$, and has a tectonic contact with the Song Cau Group (D1 $s c)$ and the Mia Le Formation (D1 $\mathrm{ml}$ ).

The Na Mo Formation (O $\mathrm{nm}$ ) composed of sandstone, quartzitic sandstone, clay shale, and siltstone yielding trilobite Ectenoglossa 
Vietnam Journal of Earth Sciences, 39(1), 76-86

sp., Lochodomas aff. yohi, Ceraurinus sp., Than Sa Formation $\left(\varepsilon_{3} t s\right)$, and shows tectonic 200-225 m thick overlies conformably the contact with the Song Cau Group (D1 sc).

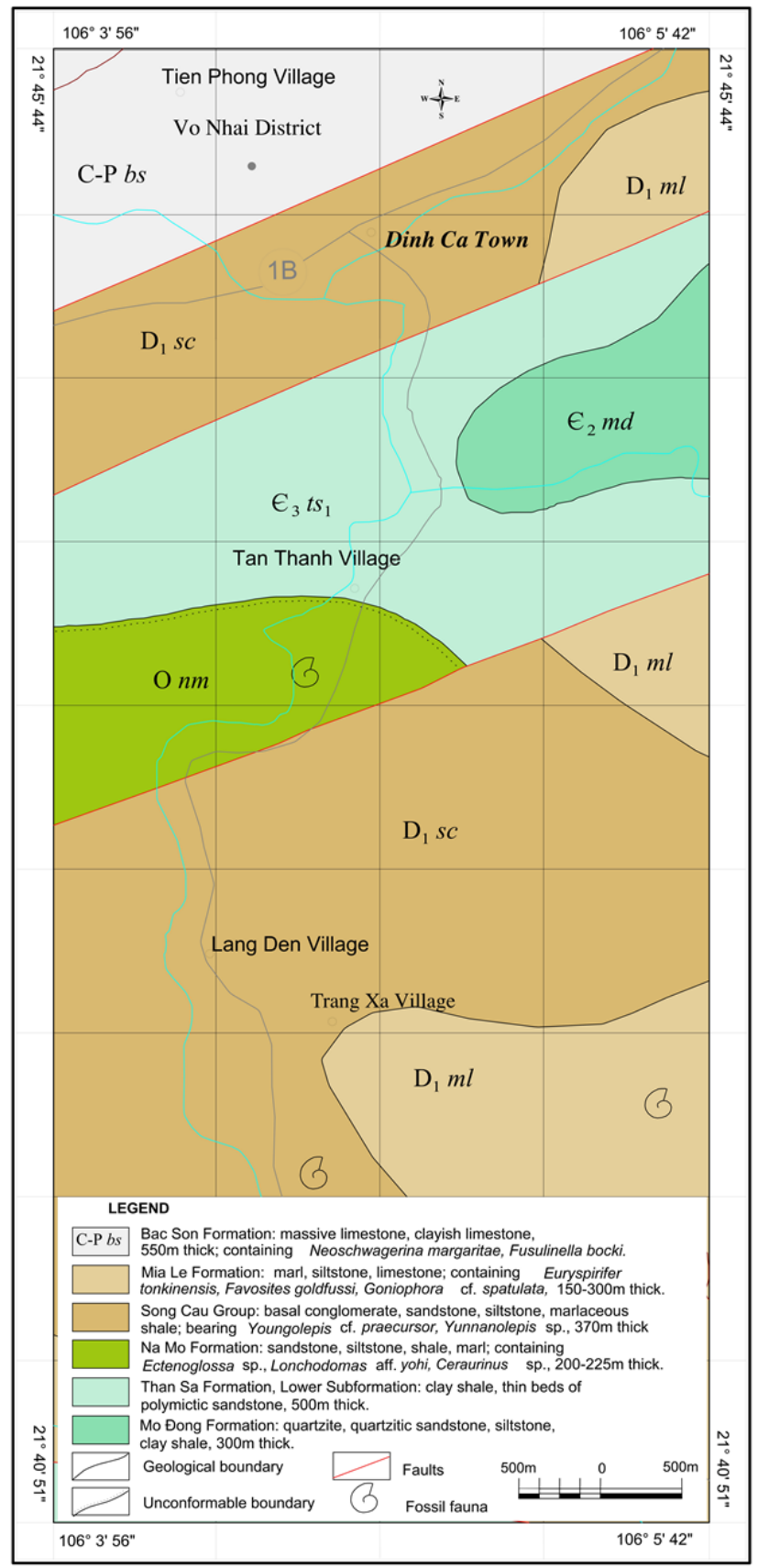

Figure 2. The Dinh Ca - Trang Xa area shown in Lang Son geological and mineral resources Sheet map at 1:200,000 scale (Doan Ky Thuy et al., 2000) 
The Song Cau Group (D1 sc) comprising basal conglomerate, gritstone, sandstone, siltstone, marlaceous shale bearing fish Youngolepis cf. praecusor, Yungolepis sp., $370 \mathrm{~m}$ thick has a tectonic contact with the Than Sa Formation $\left(\varepsilon_{3} t s\right)$, Na Mo Formation $(\mathrm{O} \mathrm{nm})$, Bac Son Formation (C-P $b s$ ), and underlies conformity the Mia Le Formation (D1ml).

The Mia Le Formation (D1 $\mathrm{ml}$ ) composed of marl, siltstone, and limestone containing brachiopod Euryspirifer tonkinensis, tabulate Favosites goldfussi, bivalve Goniopora $c f$. spatulata, 150-300 m thick overlies conformably the Song Cau Group (D1 sc), and shows tectonic contact with the Than Sa Formation $\left(\varepsilon_{3} t s\right)$.

The Bac Son Formation (C-P bs) is composed of massive limestone, oolitic limestone, clayish limestone, yielding foramiferan $\mathrm{Ne}$ oschwagerina margaritae, Fusulinella bocki, $550 \mathrm{~m}$ thick. It has a tectonic contact with the Song Cau Group (D1 sc).

\section{Materials and methods}

Five hundred paleontological samples were collected from this area. Among these two hundred specimens are graptolite fossils, some were determined by $\mathrm{Xu}$ Chen (Laboratory of Palaeontology and Stratigraphy, Nanjing Institute of Geology and Palaeontology, Chinese Academy of Sciences; 39 East Beijing Road, Nanjing 210008, China). The brachiopod, poriferan, cnidarian, mollusc, echinoderm, bryozoan and chordata (fish fossils) data cited in this study were determined by Kobayashi $\mathrm{T}$. (1960), Sokolov B. S. (1965); Tong Duy Thanh (1967), Tong Duy Thanh, Janvier Ph. (1994), Duong Xuan Hao, Pham Kim Ngan, Luong Hong Huoc, Dang Tran Huyen (1980), Le Hung (1977, 1980), Nguyen Van Liem (1978), Nguyen Huu Hung (1982) and this study.
The section bearing graptolite faunas of late Early Ordovician is exposed along the road, in south-southwestern direction from Dinh Ca Market to Dong Bo-Na Mo cross section (Figure 1 and Figure 4). In general, this section reveals an anticlinorium structure, which consists mainly of sandstone, siltstone, calcareous shale and siliceous shale rhythmically intercalated with thick-bedded sandstone. In the previous studies, this stratigraphic sequence was confusingly described by Dovjikov et al. (1965) as of the Mo Dong Formation $\left(\varepsilon_{3} m d\right)$ and showed on the North Vietnam geological map at 1:500,000 scale; or listed to the Than Sa Formation $\left(\varepsilon_{3} t s\right)$ and shown on the Lang Son geological map at 1:200,000 scale (F-48-XXIII) by Doan Ky Thuy et al. $(1976,2000)$.

Member 1: Containing medium-grained sandstone, light-colored, $4-5 \mathrm{~cm}$ bedded; yielding some crinoid stems, not well preservation, interbeds are light-colored siltstone, and black-grayish shale, thin-bedded yielded graptolite faunas. The total thickness is about $150 \mathrm{~m}$

Member 2: $50 \mathrm{~m}$ thick. The mediumgrained sandstone, greenish-grey, thickbedded; no fossils found.

Member 3: Including greenish-grey micaceous siltstone, with interbeds of brownish shale; no fossils found. The total thickness is about $150 \mathrm{~m}$

Member 4: Being named as $\mathrm{Ba}$ Nhat Member (new name) for the sediments yielding graptolite faunas. The base is characterized by fine-grained sandstone, $1-2 \mathrm{~cm}$ bedded. Directly overlying is grey siliceous shale intercalated with light-colored silstone, and black-grey calcareous shale, 1-2 mm bedded with abundant graptolite faunas (Figure 3). This member is isolated with 
Member 3 by minor fault. The total thickness is about $20 \mathrm{~m}$.

Member 5: Comprising brownish quartzitic sandstone, thick-bedded of the total thickness about $50 \mathrm{~m}$, no fossils found.

Member 6: Including grey-greenish siltstone, thin-bedded with the total thickness about $8 \mathrm{~m}$, no fossils found.

Member 7: Containing brownish sandstone, medium-bedded, having a thickness of about $10 \mathrm{~m}$; no fossils found.

Member 8: Containing greenish-grey siltstone, thin-bedded with the total thickness about $8 \mathrm{~m}$ no fossils found.

Member 9: Comprising brownish sandstone, thick-bedded with the total thickness about $80 \mathrm{~m}$, no fossils found.

Member 10: Including white-grey, greenishgrey siltstone, thin-bedded, intercalated with fine-grained sandstone with the tsotal thickness about $60 \mathrm{~m}$, no fossils found.

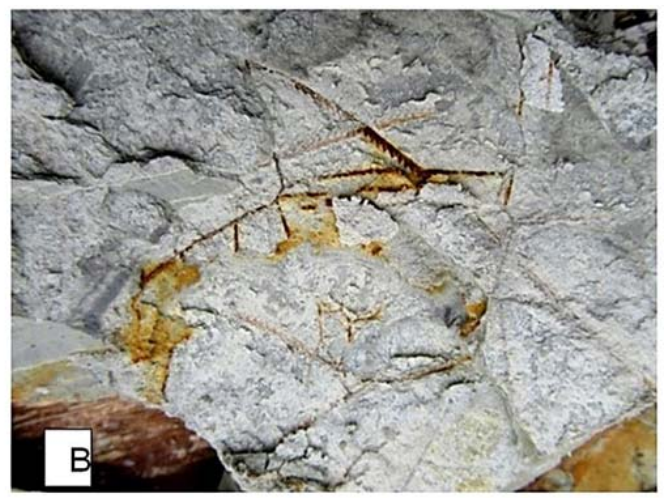

Figure 3. A. Outcrop containing late Early Ordovician graptolite faunas at the Ba Nhat Village; B. Light-colored siltstone including graptolite faunas Tetragraptus quadribrachiatus Biozone

In summary, 200 grapptolite specimens were collected in the Ba Nhat Member. Some of the samples have recently been identified by $\mathrm{Xu}$ Chen as Expansograptus urbanus (Monsen) (Figure 5A), E. abnormis (Hsu) (Figure 5B), Tetragraptus quadribrachiatus (Hall) (Figure 5D-C), Tetragraptus. approxi- matus Nicholson (Figure 5E-F), Tetragraptus. pacificus Ruedemann (Figure 6A-C), T. decipiens T.S. Hall (Figure 6D), Schizograptus sp. (Figure 6E), belonging to the quadribrachiatus Biozone. This graptolite biozone is completely disappeared at the top of the $\mathrm{Ba}$ Nhat Member.

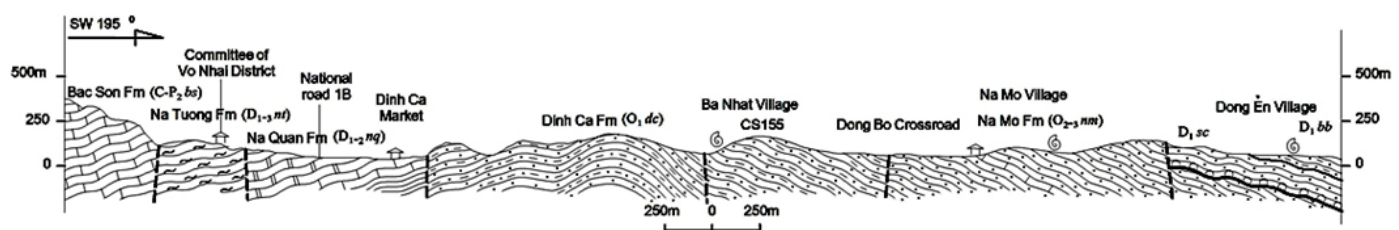

Figure 4. The Dinh Ca Market - Na Mo - Dong Bo cross section 
Nguyen Huu Hung, et al./Vietnam Journal of Earth Sciences 39 (2017)
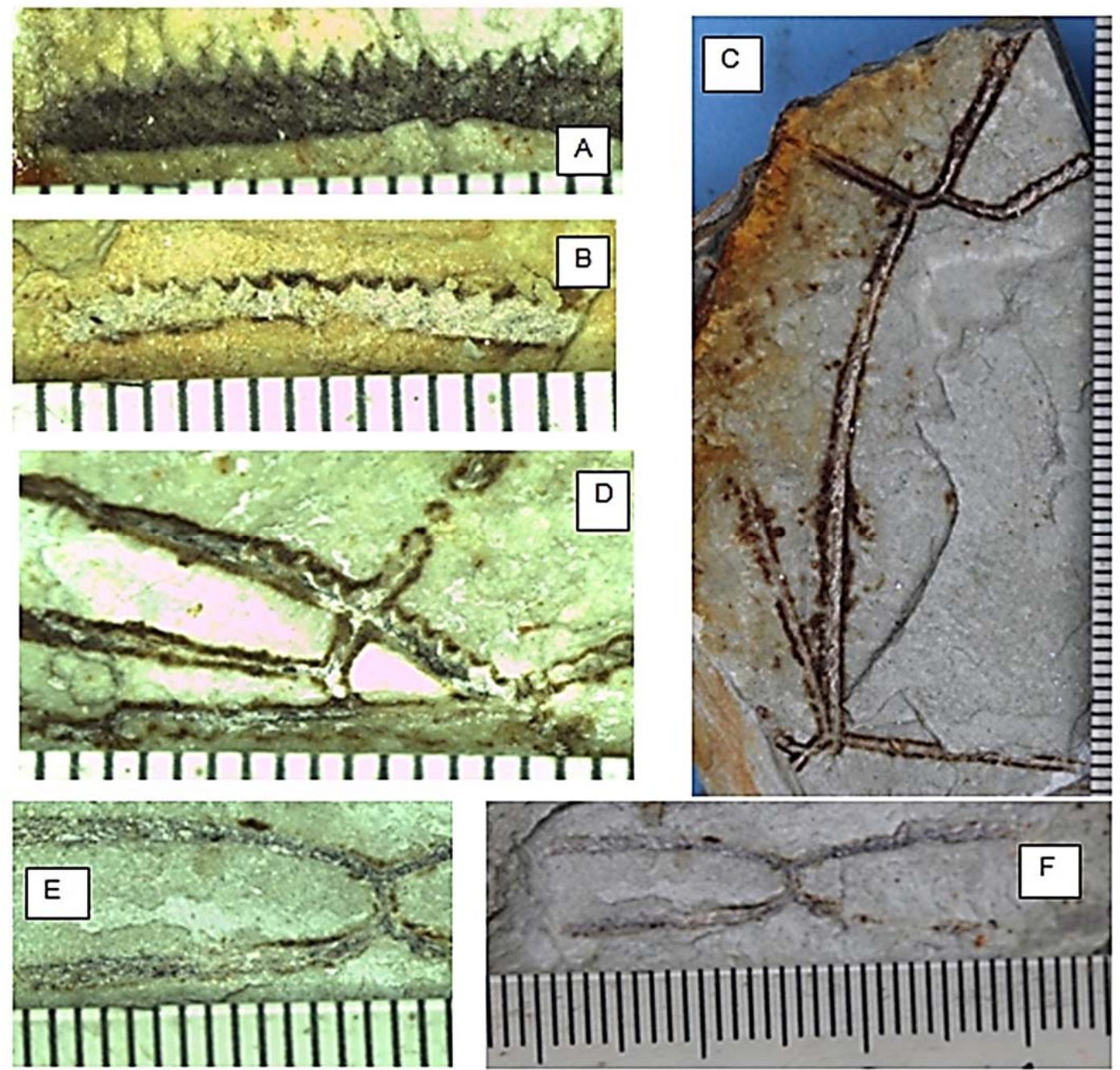

Figure 5. A. Expansograptus urbanus (Monsen), specimen no.CS155.3.1; B. Expansograptusabnormis (Hsu), specimen no.CS155.3.9; C-D. Tetragraptus quadribrachiatus (Hall) C-specimen no.CS155.3.2, D-specimen no.CS155.3.10.; E-F. Tetragraptus approximatus (Nicholson); E-specimen no.CS155.3.3; F-specimen no.CS155.2.2.The all specimens are housed in the Vietnam National Museum of Nature, Vietnam Academy of Science and Technology, 18 Hoang Quoc Viet Street, Cau Giay District, Ha Noi Capital 

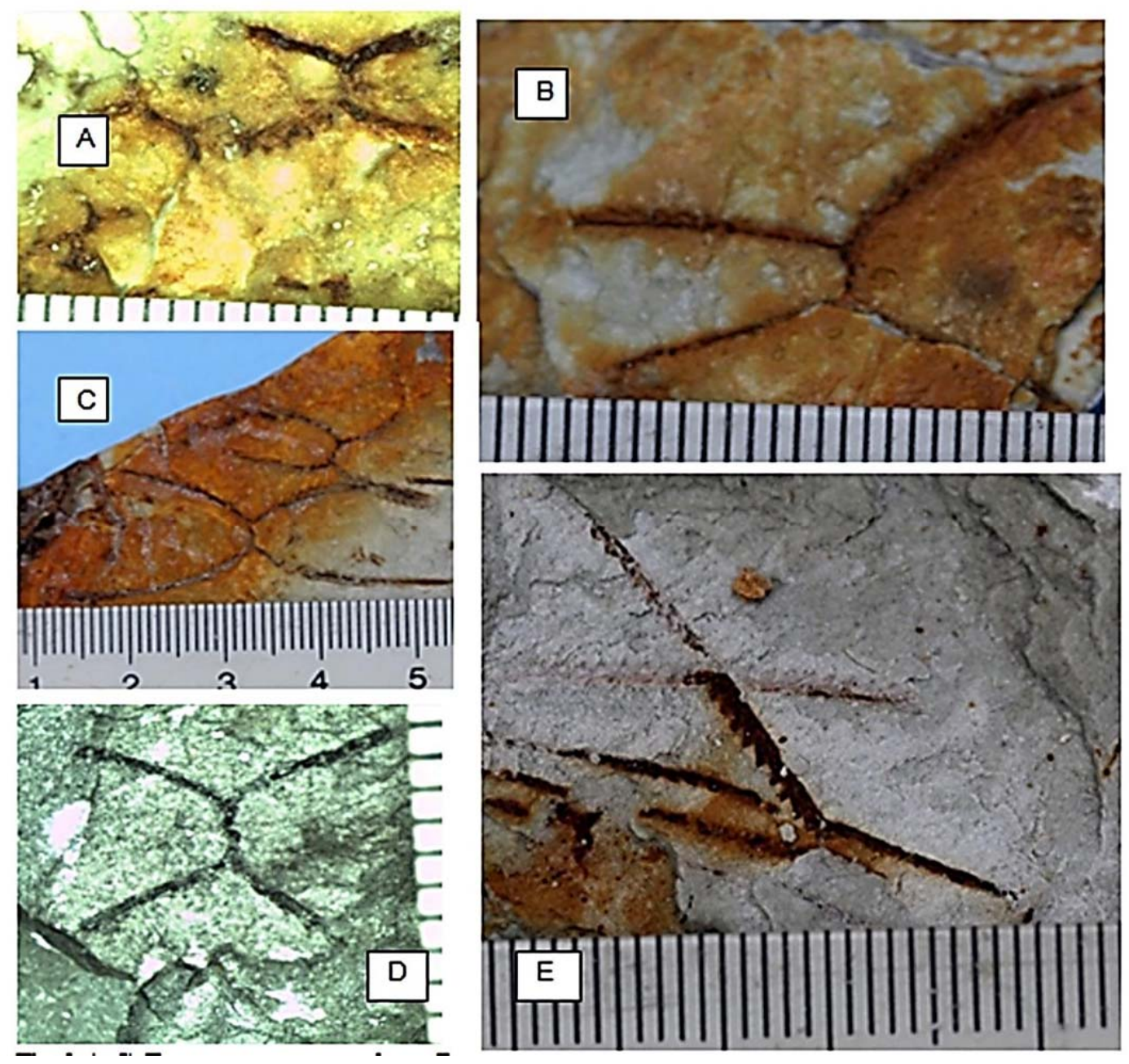

Figure 6. A-C. Tetragraptus pacificus Ruedemann; A - specimen no.CS155.2.3; B-specimen no.CS155.2.4; C - specimen no.CS155.2.5; D. Teragraptus decipiens T.S. Hall, specimen no.CS155.1.1; E. Schizograptus sp., specimen no. CS155.2.6. The specimens are housed at the Vietnam National Museum of Nature, VAST, 18 Hoang Quoc Viet Street, Cau Giay District, Ha Noi

4. Stratigraphic sequence in the Dinh CaTrang Xa area

The stratigraphic sequence of Paleozoic sediments in the Dinh Ca - Trang Xa area is shown in Figure 8.

\subsection{Late Early Ordovician sediments in the Dinh Ca Formation (newly defined)}

The late Early Ordovician graptolite faunas newly found from the Dinh Ca - Trang Xa stratigraphic section have provided important information relative to the Ordovician graptolite faunas and regional stratigraphy of the Lower Paleozoic sediments in Viet Nam. The stratigrapical and biogeoraphical significances of graptolite biozone are described as follows:

- Tetragraptus quadribrachiatus (Hall) is geographically widespread in the world. It 
was reported in the works of Hall (1858), Elles and Wood (1901), Ruedemann (1904, 1947), Berry (1960), Cooper (1979), Cooper and Fortey (1982), Tsai (1974), and Carter (1988). It was found in Alaska, Western Canada, New Zealand, Spitsbergen and Soviet Union. Recently in the Ordovician biochemostratigraphic chart (International Subcomission on Ordovician Stratigraphy, 2009) (Bergstöm 2008, Xu Chen et al. 2009), the graptolite Tetragraptus approximatus Zone is considered as the base of stage slice Fl1. Above it is the conodont Oepikodus evae Zone, belonging to F12. This interval corresponds to the lower part of Floian Stage or late Early Ordovician.

- Tetragraptus approximatus Nicholson is considered as the global graptolite Tetragraptus approximatus Biozone, that is the base for the global Florian Stage (Bergstöm, 2008). In Southwest Sweden, Tetragraptus approximatus Nicholson appeared at the lower half of the Second Stage of Lower Ordovician, including Tetragraptus phyllograptoides, Didymograptus balticus (Bergstöm, 2004).

- Expansograptus abnormis (Hsu) appears at the base of the Hentang Member corresponding to the late Early Ordovician, and completely disappears at the Upper Member of the Ningkuo Formation, corresponding to the Middle Ordovician in Zhejiang Province, South China. The other forms are Tetragraptus pacificus Ruedemann, T. decipiens T.S. Hall, Expansograptus urbanus (Monsen), Schizograptus sp., generally known in the Lower-Middle Ordovician stratigraphy of North America, Europe and China. In summary, most of the graptolite faunas from $\mathrm{Ba}$ Nhất Member showed closest relationships to the Floian (late Early Ordovician) graptolite species in the world. At present, there are a number of fossil-free gaps (or not yet found) at the section of Dinh $\mathrm{Ca}$ Formation; but hopefully the fossils will be found in both the lower and upper parts so that age of the Dinh $\mathrm{Ca}$ Formation will be completely defined.
The sediments yielded late Early Ordovican graptolites cited above may not be viewed as Upper Cambrian or of the Mo Dong Formation $\left(\varepsilon_{3} m d\right)$ as in the geologic map of northern Vietnam at 1:500,000 scale by Dovjikov et al. or the Than Sa Formation $\left(\varepsilon_{3} t s\right)$ as in the Lang Son geologic sheet at 1:200,000 by Doan Ky Thuy et al. (1976, 2000). Therefore, we propose new lithostratigraphic units for terrigenous sediments of the Lower Paleozoic stratigraphy. The Dinh Ca Formation (newly named) named after Dinh $\mathrm{Ca}$ Town, and the Ba Nhat Member (newly named) named after Ba Nhat Village, where graptolite faunas found. They are characterized by rhythmic sediments, including sandstone with intercalations of siltstone, cherty shale, and calcareous shale yielded graptolite faunas of late Early Ordovician age. The stratigraphic section from the Dinh $\mathrm{Ca}$ Market $\left(21^{\circ} 45^{\prime} 08^{\prime \prime} \mathrm{N}, 106^{\circ} 04^{\prime} 42^{\prime \prime} \mathrm{E}\right)$ to the Dong Bo-Na Mo cross section $\left(21^{\circ} 43^{\prime} 47^{\prime}{ }^{\prime} \mathrm{N}\right.$, $106^{\circ} 04^{\prime} 18^{\prime \prime} \mathrm{E}$ ) is chosen as the stratotype for the Dinh Ca Formation (Figure 4). The Ba Nhat Member is characterized by thin beds of sandstone, siltstone intercalated with siliceous shale and calcareous shale yielding abundant graptolite faunas of late Early Ordovician age. In the Song Hien Structure-facial Zone of Dovjikov et al. (1965) in Northeast Viet Nam, the Dinh $\mathrm{Ca}$ Formation $\left(\mathrm{O}_{1} d c\right)$ is distinguished from the Than Sa Formation $\left(\varepsilon_{3} t s\right)$, which was established by Tran Van Tri et al. (1964) in Than Sa area, Vo Nhai District, Thai Nguyen Province by the presence of graptolite biozones of late Early Ordovician age. It is also distinguished from the Phu Ngu Formation of Late Ordovician-Early Silurian age, which was established by Pham Dinh Long (1968) in the Phu Ngu area, Dinh Hoa District, Thai Nguyen Province by its sediments, which are free of acidic effusives but containing older graptolite biozones. The detailed sedimentary distributions in the Dinh Ca Formation in the Song Hien Structure-facial 
Zone, also elsewhere in Northeast Viet Nam should be studied in future.

\subsection{Middle-Late Ordovician sediments of the $\mathrm{Na}$ Mo Formation $\left(\mathrm{O}_{2-3} \mathrm{~nm}\right)$}

Sediments of the Na Mo Formation widely exposed in the southern side of the Dinh Ca$\mathrm{Na}$ Mo section (see Figure 4) are composed of thick-bedded quartz sandstone with interbeds of sandstone, siltstone containng trilobite, brachiopod faunas of Middle Ordovician age.

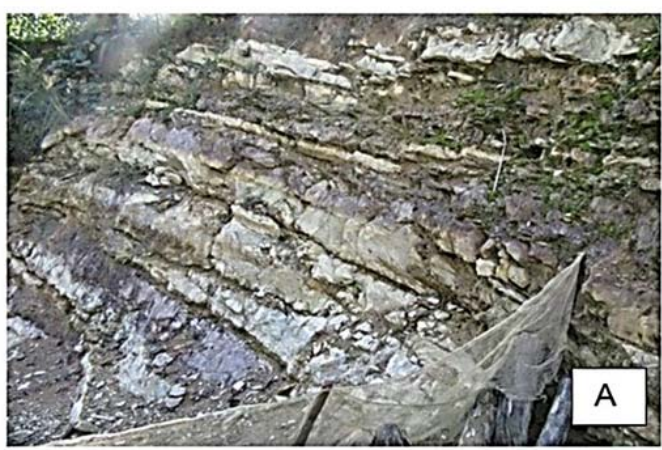

Figure 7. A. Light-colored limestone, thick-bedded at left hillside; B. Light-colored limestone of the Na Mo Formation widely exposed to the left of the road, km 3.7 toward Trang Xa

\subsection{Devonian sediments}

The Devonian sediments are largely spread. Five lithostratigraphic units are being proposed here. At the southern side of the section in the Dong En Village exposed cropped out are red conglomeratic sandstone beds yielding some fish remains, asigned to the $\mathrm{Si}$ Ka Formation $\left(\mathrm{D}_{1} s k\right)$. It lies unconformably on the Na Mo Formation, but locally, some of the beds are cut by small-scaled faults. The Early Lochkovian age of the Si Ka Formation is based on the correlation with stratotype of the formation bearing fish, crutacean, plant fossils in the Dong Van area, Ha Giang Province. Directly above are calcareous siltstone yielded abundant brachiopod Howellella mercuri, Howittia wangi; fish Yunnanolepis cf. praecusor, Y. meemannae, Chuchinolepis cf.dongmoensis, Zeaspis sp., Nostolepis sp., Langdenia campylognathus; tabulate $\mathrm{Fa}$ vosites aff. intricatus, Squameofavosites ko-

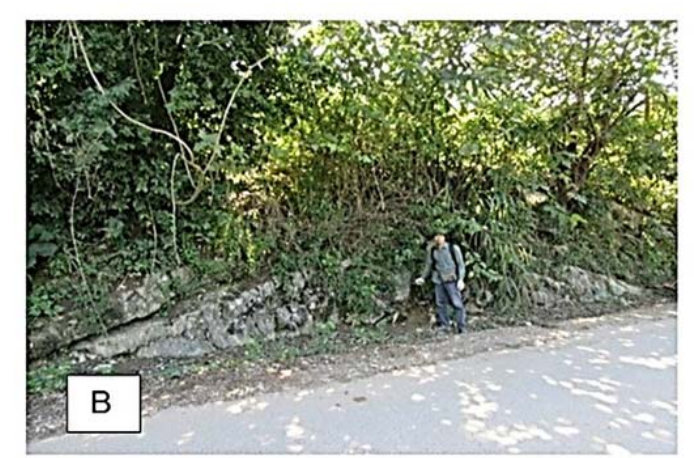

In the upper part of the formation are interbeds of light-colored limestone (Figure 7A, B) which in the E. D. Vaxilevxkaja's original description (Dovjikov et al., 1965), these limestones yielded heliolitoid coral Plasmoporella of Late Ordovician age. Presently, limestone beds are well exposed along the local road, to the left hillside, about $300 \mathrm{~m}$ southwest of the Dong Bo-Na Mo cross section. The contact with the underlying Dinh Ca Formation is cut by minor faults running in east-west direction.

lymaensis, Thamnopora incerta showing Late Lochkovian-Early Pragian age, being assigned to the Bac Bun Formation. Overlying conformably the Bac Bun Formation are marble and dark-grey calcareous shale of the Mia Le Formation $\left(\mathrm{D}_{1} \mathrm{ml}\right)$, including abundant brachiopod, coral, bivalve, stromtoporoid, crinoid faunas belonging to the Euryspirifer tonkinensis assemblage of the Late Pragian-Early Emsian age. Overlying conformably the Mia Le Formation are mainly limestones bearing abundant coral and stromatoporoid faunas suggesting the Late Emsian-Early Eifelian age, and assigned to the $\mathrm{Na}$ Quan Formation $\left(\mathrm{D}_{1-2} n q\right)$. Found in the northeastern side of the section, at the Dinh Ca bridge is a tectonic fault of NE-SW direction, which spreads along a stream of north flank of the terrigenous mountain range of the Dinh Ca Formation $\left(\mathrm{O}_{1} d c\right)$. On the valley from the Dinh $\mathrm{Ca}$ Town to the Ve Bridge exposed are lightcolored limestones yielding poriferan Amphi- 
pora, Stachyodes, Trupetostroma, Chaetetes and coral, brachiopod fossils belonging to the $\mathrm{Na}$ Quan Formation $\left(\mathrm{D}_{1-2} n q\right)$. Directly above, on the hills around the Dinh Ca Town outcropped are siliceous shale bearing tentaculitid Stiatostyliolina sp., Viriatellina sp., Styliolina sp. showing the Late Emsian-Frasnian age, and assigned to the $\mathrm{Na}$ Tuong Formation $\left(\mathrm{D}_{1-3} n t\right)$.

\subsection{Carboniferous-Permian sediments}

Along the northwestern direction near the Committee Building of Vo Nhai District, above the $\mathrm{Na}$ Tuong Formation cropped out are mainly thick-bedded limestones of the Bac Son Formation $\left(\mathrm{C}-\mathrm{P}_{2} b s\right)$ bearing abundant foraminifers of zones Dainella, Endothy anopsis, Millerella, Profusulinella, Fusulinella, Obsoletes, Triticites, Schwagerina, Robustoschwagerina, Misellina and Neoschwagerina. The Bac Son Formation ranges from the Lower Carboniferous (Visean stage) to the upper Middle Permian (Capitanian stage), and has the tectonic contact with the $\mathrm{Na}$ Tuong Formation.

In general, the structure of the stratigraphic section from the Committee Building of Vo Nhai District, northsouthern direction passing by the Dinh Ca Market to Trang Xa Village (Fig. 8) is an anticlinorium, whose core is filled by sediments of the Dinh Ca Formation, bearing global Tetragraptus quadribrachiatus graptolite Biozone of late Early Ordovician age.

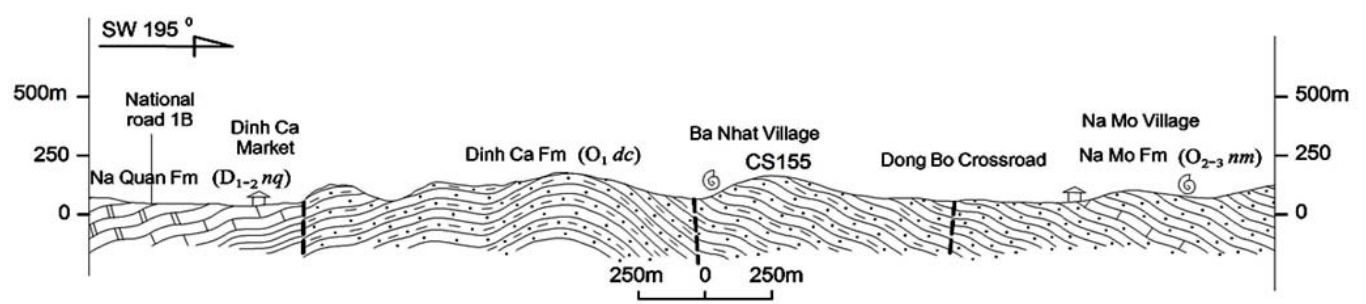

Figure 8. Geologic section from the Committee Building of Vo Nhai District passing by the Dinh Ca Market to the Trang Xa Village

\section{Conclusion}

The discovery of Early Ordovician graptolithina plays an important role for stratigraphic correlation of Lower Paleozoic sediments in Northern Vietnam. It serves as the basic data for establishing new lithostratigraphic unit termed as the Dinh Ca Formation in the northeastern region of Vietnam.

\section{Acknowledements}

The study was conducted as part of the project "Paleontological collection in Vietnam territory from 2015 to 2020 " funded by Vietnam Academy of Science and Technology coded BSTMV.28/15-18 to whom we sincerely acknowledge. The authors are grateful to
Prof. Acad. Xu Chen, Institute of Geology and Palaeontology, Chinese Academy of Sciences for identification of the graptolite faunas. We thank Mr. Nguyen Duc Phuong, driver of the Trung Kien Tourist and Trading Co Ltd., for essential information on the outcrop of Ordovician graptolite faunas in the $\mathrm{Ba}$ Nhat area.

\section{References}

Bergstöm S. M., Löfgren A., and Maletz J., 2004. The GSSP of the Second (Upper) Stage of Lower Ordovician Series: Diabasbrottet at Hunneberg, Province of Västergötland, Southwestern Sweden. Episodes, 27(4), 265-272.

Bergstöm S. M., Chen X., Gutierrez-Marco J.C., and Dronov A. V., 2008. The new chronostratigraphic classification of the Ordovician System and its rela- 
Vietnam Journal of Earth Sciences, 39(1), 76-86

tions to major regional series and stages to $\delta^{13} \mathrm{C}$ chemostratigraphy. LETHAI, 42(1), 97-107.

Dovjikov, A. E. (ed) et al., 1965. (1971 in Vietnamese). The Geology of the Northern part of Vietnam. Geological Survey of Vietnam, Ha Noi, 583p.

Doan Ky Thuy (Ed.), 1976. Geologyof the Lạng Sơn sheet (F-48-XXIII), 1:200.000 scale. Housed in the Central of Geological Information and Archives (in Vietnamese), Ha Noi.

Doan Ky Thuy (Ed.), 2000. Geology and mineral resources of the Lạng Sorn sheet (F-48-XXIII), 1:200.000 scale. Published by Department of Geology and Minerals of Viet Nam (in Vietnamese with English summary), Ha Noi.

Le Duy Bach, 1985. Structure and formation stages of Viet Nam in the tectonic framework of SE Asia. Abstract of PhD Dissertation (in Russian). The National Library of Viet Nam, 31 Trang Thi Street, Ha Noi.

Mansuy H., 1908. Contribution à la carte géologiques de 1'Indochine. Paléontologie, 73 pp., Ha Noi.

Nguyen Van Liem, 1978. On the Carboniferous system in North Viet Nam (in Vietnamese). Journal of Biology-Geosciences, 16(3), 78-85.

Patte E., 1927. Études géologiques dans l'Est du Tonkin. Bull. Serv. Géol. Indoch., vol. XVI, fasc. 1, 314pp, Ha Noi.

Pham Dinh Long (Ed.), 1968. Geology of the Tuyen Quang sheet (F-48-XXII), 1:200.000 scale. Housed in the Central of Geological Information and Archives. Ha Noi (in Vietnamese).
Pham Dinh Long, Hoang Xuan Tinh, Phan Viet Ky, 1981. Some main features of regionalgeology of Northeast Viet Nam. Mapping, 48, 4-19, Ha Noi.

Pham Kim Ngan, 1975. Some biostratigraphical sections of the Lower Paleozoic of North Viet Nam. Collections of works onstratigraphic studies in Viet Nam, 40-54. Science and Technics Publishing House (in Vietnamese), Ha Noi.

Pham Kim Ngan, 1982. Some research results of the Cambrian and Ordovician biostratigraphy in Viet Nam. Geology and Minerals, 1, 7-17. Published by Institute of Geology and Mineral resources (in Vietnamese with English summary), Ha Noi.

Saurin E., 1956b. Lexique stratigraphique international. Vol. III, fase, 6a: Indochine. Centre National de la Rech. Scient., 140p. Paris. 1970: published by Science and Technics Publishing House, 222pp. (in Vietnamese), Ha Noi.

Tong Duy Thanh, Vu Khuc (Eds.), 2011. Stratigraphic units of Viet Nam.Vietnam National University Publishing House, 526pp, Ha Noi.

Tran Van Tri, Ta Hoang Tinh, Phan Son, Le Duc An, 1964. On the Lower Paleozoic sediments in the Than Sa area. Journal of Geology, series A, 37, 6-11 (in Vietnamese with Russian summary), Ha Noi.

Tran Van Tri, Vu Khuc (Eds.), 2011. Geology and Earth resources of Viet Nam. Publishing House for Science and Technology, 645pp, Ha Noi.

$\mathrm{Xu}$ Chen, Strig M. Bergström, Yuan-Dong Zhang and Jun-Xuan Fan, 2009. The base of the Middle Ordovician in China with special reference to succession at Hengtan near Jiangshan, Zhejiang Province, Sothern China. LETHAI, 42, 218-231. 